\title{
AN OVERVIEW OF FOREIGN INVESTMENT LAWS ENFORCED IN PAKISTAN
}

\author{
Muhammad Khalid Hayat ${ }^{*}$
}

\begin{abstract}
This research paper examines the foreign investment laws and procedure of Pakistan and their role in protection of foreign investment in Pakistan. These laws are untapped area of research and one cannot find any specific research tracing the legal development in this highly specialized field. So far Pakistan has 48 BITs enforced with different countries and has also signed ICSID Convention, which is promulgated locally through Arbitration (International Investment Disputes) Act, 2011 incorporating the Convention in the schedule to ease the difficulty of foreign investors to enforce the awards rendered under auspices of ICSID in the territory of Pakistan. Under this research, an attempt has been made to study prevalent foreign investment laws and its trends in Pakistan. Though Pakistan has significantly improved its foreign investment regime by introducing new investor's friendly laws like, Special Economic Zones Act, 2011 and Investment Policy, 2013 etc., apart from its previous legislation on the subject, yet this regime needs more improvement and updating. Extensive overview of all existing foreign investment laws were carried out in this research. Fair and Equitable Treatment, Expropriation and other factors affecting foreign investment laws are the areas, which need to be taken care of by policy maker in the existing foreign investment laws of Pakistan. With these aims, it is hoped that this research paper would be a humble contribution in the literature on the subject.
\end{abstract}

Keywords: Foreign investment law, world globalization, economic well-being, BIT, ICSID

\section{Introduction}

Foreign Investment is a highly specialized yet very important subject for both developing and developed countries alike. Foreign investment is also known as international investment, which is getting more importance due to the fact of overall socio-economic scenario of the world. The world after globalization is fast shrinking. Every country is dependent on the other in one way or the other for its economic wellbeing. With the aim of getting more profits on income, the countries encourage their persons or nationals or private enterprises to start making foreign investment in other countries especially third world countries to reap profits on their investment as these countries are short of fund but enriched with natural resources. Thus, in this way, new subject of international investment was formed. Due to multiple angle investment, the need of some protection to foreign investment at the level of countries were also felt,

"Muhammad Khalid Hayat, Ph.D. Student, Faculty of Law, University of Karachi 
which gave birth to international investment law and the genre of treaties commonly known as Bilateral Investment Treaties (BITs). Moreover, International platform for redressal of the private investment disputes between states and private investors including companies were also established under the International Convention with the name of 'International Center for Settlement of Investment Disputes', commonly known as 'ICSID' to resolve investment disputes between states and nationals of other states ${ }^{1}$ as these entities/persons unlike states, have no recourse for settlement of their disputes as those are available to states under international Law i.e. International Court of Justice.

\section{Foreign direct Investment}

Foreign Direct Investment (FDI) literally means an investment in the domestic structure, equipment and organization by Multinational Corporations (MNCs) and Transnational Corporations (TNCs) into the host country with the purposes to obtain profit on one hand and to transfer technology, skills and best practices on the other. Some of the authors describe the definition of FDI as a process whereby residents of one country (the source country) have ownership of assets located in another county for the purposes to control the production, distribution and other activities of the firm ${ }^{2}$. It is indeed durable and generally useful for the host country in both shorter and in longer run. It creates advantages for technological starved third world countries as they receive both technology and valuable foreign exchange in return, which helps support their weakened and vulnerable economy. Generally, FDI are of two types i) inward FDI and ii) Outward FDI. These two are components of net FDI inflow. The International Monetary Fund's Balance of Payments manual defines the "Foreign Direct Investment as an investment that is made to acquire the lasting interest in a firm or an enterprise operating in country other than investor, thereby, the investor have effective voice in management of firm/enterprise. FDI is directed usually from technologically advanced country to third world countries. The impact of FDI on recipient country results into increasing return in domestic production".

As compared to historical perspective, due to globalization, the meaning of FDI has transformed itself into more vibrant terminology ${ }^{3}$. According to International Investment Theory, investment raises the standards of inhabitants' living in any country, creates jobs; expands economy and brings in technical knowledge and best practices, which can transform the socio-economic landscape of host country. It usually involves participation in management, joint venture transfer of technology and technical knowhow. The investment of long-term is of significant importance in FDI. It is distinguishable from Portfolio investment, which is described as short term investment and has a high turnover of securities ${ }^{4}$.

\footnotetext{
${ }^{1}$ The Convention was signed at Washington $18^{\text {th }}$ March, 1965. Some of the states have adopted it through their local laws as an act of parliament, like Arbitration (International Investment Disputes) Act, 1966 by England.

${ }^{2}$ Imad A. Moosa, Foreign Direct Investment: Theory, Evidence and Practice(New York: PALGRAVE, 2002), $1-2$

${ }^{3}$ Ibid.

${ }^{4}$ Ibid.
} 


\section{Foreign Investments Laws Enforced in Pakistan}

Regulatory framework for foreign investment in Pakistan consists of national laws and BITs executed by Pakistan with other countries. The national laws ${ }^{5}$ over foreign investment are as follows:

1) Foreign Private Investment (Promotion and \& Protection) Act, 1976

2) The Protection to Economic Reforms Act, 1992

3) Board of Investment Ordinance, 2002

4) Arbitration (International Investment Disputes) Act, 2011

5) Recognition and Enforcement (Arbitration Agreements and Foreign Arbitral Awards)

Act, 2011

6) The Special Economic Zones Act, 2012

7) Investment Policy, 1997

8) Investment Policy, 2013

9) Bilateral Investment Treaties of Pakistan

Foreign investment in Pakistan is also regulated by Foreign Exchange Regulation Act, $1947^{6}$. The remittance arising out of foreign investment is treated as repatriates subject to rules and regulations of State Bank of Pakistan. However, with certain modifications, these rules are relaxed under the first two enactments. The Government of Pakistan has signed Bilateral Investment Treaties with 47 countries and Avoidance of Double Taxation Treaties with 53 countries $^{7}$. In the year 2013, the Federal Government in order to facilitate and to liberalize foreign investment has also issued Foreign Investment Policy, $2013^{8}$. There are also some of the investment disputes under the BITs of Pakistan, which were concluded by ICSID ${ }^{9}$, the International Agency of World Bank for

\footnotetext{
${ }^{5}$ http://www.kpmg.com/PK/en/IssuesAndInsights/ArticlesPublications/Documents/Investment-inPakistan2013.pdf (accessed January 1, 2015)

${ }^{6}$ Foreign Investment Regulation

Review,http://www.mjlalegal.com/uploads/1/7/8/7/17874169/foreign_investment_regulations__pakistan.pdf(accessed May 09, 2015)

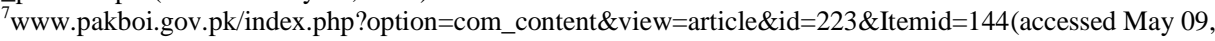
2015)

${ }^{8}$ Investment Policy, 2013,http://www.boi.gov.pk/UploadedDocs/Downloads/InvestmentGuide.pdf (accessed May 09, 2015)

${ }^{9}$ Some of list of cases concluded by ICSID over Pakistan under different BITs are listed at this website. For detail view see,

https://icsid.worldbank.org/apps/ICSIDWEB/cases/Pages/AdvancedSearch.aspx?rntly=ST105(accessed May 10, 2015)
} 
providing the services of Arbitration in investment disputes ${ }^{10}$. ICSID is an international investment arbitration platform that facilitates disputes resolution and conciliation between international investors and states ${ }^{11}$.

Foreign Private Investment (Promotion and \& Protection) Act, $1976^{12}$ is a special law promulgated by an act of Parliament in the year 1976 to give legal cover to international investors and their investment in Pakistan ${ }^{13}$.Primarily this enactment was promulgated for promotion and protection to foreign investment in Pakistan. It has given legal cover to all industrial undertakings established after first of September, 1954, if they have prior approval from the Government of Pakistan. The provisions of the act are applicable on all industrial undertakings or setup thereof. The protections in the Act are available to foreign investment in addition to protection available to foreign investment under bilateral investment treaty. It has total eleven sections. The section 3 of the Act provides for field for foreign investment on which the discretion was given to the Federal Government to open any sector of economy for foreign private investment ${ }^{14}$. The dissection of this section reveals that the discretions are exercisable by the Government keeping in view special areas of interest relating to economy. These include investment relating to economic and social needs of the country, which could also contribute to resources of Pakistan. The investment having option to strengthen the balance of payments, discovery, mobilization or better utilization of natural resources are stressed. Section 4 provides for approval of Foreign Private Investment from the government of Pakistan. The most important section of the enactment are section 5,6 and 7 , which relate to protection of foreign private investment agreements ${ }^{15}$ and repatriation facilities of proceeds and funds to the country from where it was originated. Amongst other, these are sub-divided into three categories; (i) original investment, (ii) profits on original investment, and (iii) additional amount resulting from the re-invested profits $^{16}$. The remittance earned by foreign employees' national working in any industrial undertaking in Pakistan and their repatriation are subject to rules and regulations or orders by Federal Government and State Bank of Pakistan ${ }^{17}$.

The Protection to Economic Reforms Act, $1992^{18}$ was also enacted by Government of Pakistan as an act of parliament to provide protection to economic reforms carried out in the late $1990^{19}$. The economic activity as per the Act includes all economics policies, laws, programs, regulations announced, promulgated or implemented and privatization

\footnotetext{
${ }^{10}$ https://icsid.worldbank.org/apps/ICSIDWEB/about/Pages/ICSID\%20And\%20The\%20World\%20Bank\%20 Group.asp(accessed May 10, 2015)

'ICSID',http://en.wikipedia.org/wiki/International_Centre_for_Settlement_of_Investment_Disputes(accessed May09, 2015)

${ }^{12}$ http://boi.gov.pk/UploadedDocs/Downloads/InvestementActs.pdf (accessed May 11, 2015)

${ }^{13}$ Alishba Tahir, "Developing Countries International Investment Policies, Unveiling Pakistan

Paradoxies"http://works.bepress.com/alishba_tahir/1(accessed May 09, 2015)

${ }^{14}$ See section 3 of the Act.

${ }^{15}$ See section 5 of the Act

${ }^{16}$ See section 6 of the Act

${ }^{17}$ See section 7 of the Act

${ }^{18} \mathrm{http}: / /$ boi.gov.pk/UploadedDocs/Downloads/InvestementActs.pdf (accessed May 09, 2015)

${ }^{19}$ See preamble of the Act
} 
of public sector enterprise ${ }^{20}$. This act has scattered over 11 sections. Section 4 provides for the freedom to bring, hold, sell and take out Foreign Currency without Foreign Currency Declaration at any stage by foreign investors ${ }^{21}$. Likewise, section 5 of the Act talks about foreign currency account which were made immune from tax authorities. These accounts are also exempted from levy of wealth tax and compulsorily deduction of Zakat. The State Bank of Pakistan was also restricted through section 5(2) for imposing any restrictions on these accounts on deposits and withdrawal ${ }^{22}$. Section 6 and 7 provides for protection of fiscal incentives for setting industries and transfer of ownership to private sectors. Any incentives and enterprise transferred by Government to any person cannot be compulsorily acquired or taken over by Government which shows that there is a substantial protection and coherence to policies and rules of investment are provided in Pakistan. No enterprise was compulsorily acquirable by Government of Pakistan belonging to foreign and Pakistani national ${ }^{23}$. All banking transaction by all banks and Financial Institutions regarding foreign currency accounts of foreign investment ought to be done ${ }^{24}$. Section 10 says that all financial obligation incurred by previous government under any instruments, the same shall continue to be in force and shall not be altered.

The Board of Investment is autonomous body established by an act of parliament as an apex agency to encourage both local and foreign investment ${ }^{25}$. The primary function of the body is to attract, facilitate and to promote foreign investment in Pakistan. It tried to serve one-window interface for foreign and national investors in all sectors of economy ${ }^{26}$. Originally, this body was established as Pakistan Investment Board and was headed by the Prime Minster of Pakistan as President of Board. It was lateron, merged into as an attached department of Ministry of Industries and Production in 1996, thereafter, in the year 2003, it was transferred to Ministry of Privatization and Investment. In 2003, the BoI became a division in the Ministry of Investment. In the year 2009, due to re-organization and abolishing of Ministry of investment, the BoI was placed under the Prime Minister's Secretariat. The BoI is also active member of World Association of Investment Promotion Agencies (WAIPA) ${ }^{27}$. The main objective of BoI is to support long term and sustainable economic growth through friendly investment in Pakistan. It also provides investment related services, promotion material and highlighting different sectors of Pakistan, which are lucrative for investors. BoI has a major role to play in stimulating the investment. It also serves as an apex body to give advices to different agencies regarding investment and liaising with other international investment promotion agencies. Unlike, previous decade, the BoI has attracted US\$ 21

\footnotetext{
${ }^{20}$ See section 2(b), which provides for economic reforms

${ }^{21}$ See section 4 of the Act,

${ }^{22}$ See section 5 of the Act

${ }^{23}$ See section 8,9 of the Act

${ }^{24}$ See section 9 of the Act

${ }^{25}$ It was established byBoard of Investment Ordinance 2001, promulgated vide F. NO. 2 (1)/2001 -Islamabad the 22nd March, 2001, the details are available athttp://boi.gov.pk/AboutUs/BOIOrdinance.aspx(accessed May $11,2015)$

${ }^{26} \mathrm{http} / / /$ boi.gov.pk/AboutUs/AboutUs.aspx(accessed(accessed May 11, 2015)

${ }^{27}$ The official website of World Association of Investment Promotion Agencies (WAIPA)

http://waipa.org/(accessed May 15, 2015)
} 
billion in foreign investment in this decade, whereas in previous decade, the BoI attracted Rs.3 billion.

Arbitration (International Investment Disputes) Act, 2011 is national legislation enacted by Government of Pakistan to implement International Convention for establishment of ICSID to resolve International Investment Disputes ${ }^{28}$. The schedule of the act carries the International Convention for establishment of Center for Settlement of Investment Disputes $^{29}$, the prime body for settlement of international investment disputes. The move of enacting the national legislation was with the purpose of restoring the confidence of international investors in Pakistan. This much awaited legislation was being looked over by many peoples in wake of decision of Supreme Court of Pakistan in the case of SGS versus Pakistan ${ }^{30}$, whereby it was observed by the Supreme Court of Pakistan that although Pakistan is signatory to the Convention, but the same was not made part of national legislation, therefore, the Pakistani Courts are not bound to stay the proceedings initiated in their court following commencement of ICSID Arbitration. The international proponent argues that such enactment is good sign as now the enforcement of ICSID award in Pakistani court is easier as compared to many other states, where awards are left to the civil procedural provisions ${ }^{31}$. Previously, the ICSID convention was promulgated through an ordinance in the year 2007, but due to constitutional changes in Pakistan, the same lived for 120 days. Later on, the Supreme Court of Pakistan revalidated all acts, legislation and orders in the year 2008 in the famous case of Tikka Khan ${ }^{32}$, which judgment gave impetus to the legislation for further two years till the year 2009, where deposed judges of Supreme Court after re-taking the charge ordered that all previously legislations in the era of Musharraf ought to be revalidated from Parliament ${ }^{33}$. President Zardari after the judgment, two times promulgated the legislation through Ordinances, but finally, it was made an act of Parliament in the year 2011.

The Section 3 of the Act defines registration of award, which is deemed to have been rendered by ICSID. For the purposes of execution, the award shall be treated a judgment of High court. The Exemption to the Government is provided under section 5 of the Act, where any award in which the Government was not party, cannot be enforced against the Government ${ }^{34}$. The exclusiveness of the Act can be observed from the fact that the local version of Arbitration Act, 1940 is done away and their provisions are not applicable on the proceedings of the Act ${ }^{35}$. The Act further provides Article18, 19, 20,

\footnotetext{
${ }^{28}$ Full version of the Act is available at the website of National Assembly of Pakistan on http://www.na.gov.pk/uploads/documents/1304997073_250.pdf, (accessed May 12, 2015)

${ }^{29}$ See Schedule of the Act, which is incorporated in the Act verbatum

${ }^{30}$ See, Societe General Surveillance versus Pakistan, 2002 SCMR 1694

${ }^{31} \mathrm{http} / / / \mathrm{kluw}$ rarbitrationblog.com/blog/2011/06/16/pakistan-enacts-a-statute-to-implement-the-icsidconvention/

${ }^{32}$ See Tikka Iqbal Muhammad Khan versus General Pervez Musharraf and others, reported as PLD 2008

Supreme Court, page 25 and 178

${ }^{33}$ Ahmed Ghouri, (2013) Law and Practice of Foreign Arbitration and Enforcement of Foreign Arbitral in

Pakistan

${ }^{34}$ See section 3,4 and 5 of the Act.

${ }^{35}$ See section 6 of the Act
} 
21(a) and 22 as these are applicable to Article 21(a), 23(1) and 24 and shall have force of law. The schedule of the Act carries with ICSID Convention ${ }^{36}$.

Recognition and Enforcement (Arbitration Agreements and Foreign Arbitral Awards) Act, $2011^{37}$ (hereinafter referred to as "AAFA, 2011 ") gives effect to Convention on the Recognition and Enforcement of Foreign Arbitral Awards (New York Convention) 1958, commonly known as "New York Convention" ${ }^{38}$. Previously, there was the Arbitration (Protocol and Convention) Act of 1937 to give legal cover to the Protocol on Arbitration Clauses and the Convention on the Execution of Foreign Arbitral Awards (Geneva Convention) 1927, which however, was repealed by former enactment ${ }^{39}$.Under the scheme of AAFA, 2011, the High Court of respective provinces of Pakistan has been given the powers to enforce and recognize the foreign arbitral awards, whereas, anyone person can file a prescribed application under section 6 of the $\mathrm{Act}^{40}$. On 10-06-1958, the Convention on Recognition and Enforcement of Foreign Arbitral Awards was adopted by United Nations. This Act recognizes the international obligation of Pakistan as per provisions of Convention and provisions of Convention are made to prevail than the provisions of act in case of any inconsistency ${ }^{41}$. Pakistan was one of the first signatories of the New York Convention in 1958 but did not ratify it until 2005. A temporary ordinance was promulgated that year to give effect to the Convention and was periodically renewed by presidential ordinances. However, following the declaration of emergency and the ensuing restoration of the deposed judiciary, the legislation expired in August 2010. This Parliamentary enactment puts an end to much uncertainty surrounding the enforcement of foreign arbitral agreements and awards in Pakistan and ensures that the legal system in Pakistan is at least at par with similar enforcement regimes in the international comity of nations ${ }^{42}$.Under the Act, in pursuance to Article II of the Convention, an application to stay the legal proceeding pending arbitration proceeding can be filed in the High Court as long as the arbitration proceedings are not concluded $^{43}$. Along with application for recognition and enforcement of Arbitral Awards, as required in Article IV of Convention, the parties shall file documents in support of the application ${ }^{44}$. It is interesting to note that under the scheme of this Act, no discretion has been conferred upon the Pakistani courts even on the ground of

\footnotetext{
${ }^{36}$ See Schedule to Act, which is reproduction of ICSID convention

${ }^{37}$ The Act was published in the Official Gazette of Pakistan through ACT XVII of 2011 on 19-07-2011. It was enforced at once. The name of the legislation is provided in the section 1 of the Act and is known as Recognition and enforcement (Arbitration Agreements and Foreign Arbitral Awards) Act 2011 and be accessed online at http://www.na.gov.pk/uploads/documents/1311664767_452.pdf(accessed May 20, 2015)

${ }^{38}$ See Preamble to the Act, which specifically provides for arbitration agreement and foreign arbitral award rendered under the New York Convention, 1958.

${ }^{39}$ See section 10 of the Act

${ }^{40}$ See section 6, where foreign arbitral award has to be recognized and enforced like judgment and order of the Court

${ }^{41}$ See Second Recital of the act,, section 8 of the act provides for inconsistency between the provisions of Act and provisions of Convention, and incase of any inconsistency, the provisions of Convention would prevail

${ }^{42}$ Commentary by Mr.ShaharyarNashat on the Recognition and Enforcement (Arbitration Agreements and Foreign Arbitral Awards) Act, 2011 http://www.counselpakistan.com/vol-

3/from_the_editors/by_shaharyar_nashat.php(accessed May 20, 2015)

${ }^{43}$ Section 3 of the Act provides for Jurisdiction of Courts, where any legal proceedings can be stayed pending Arbitration Proceedings in wake of Convention

${ }^{44}$ See section 5 of the Act
} 
inconvenience as observed by High Court of $\operatorname{Sindh}^{45}$.Recognition and Enforcement (Arbitration Agreements and Foreign Arbitral Awards) Act, 2011 deals with commercial award enforcement matters whereas Investment awards are enforced under Arbitration (International Investment Disputes) Act, 2011, especially, under section 6 (Art. 53) of International Convention for establishment of Center for Settlement of Investment Disputes.

Internationally, in order to bring technology and the investments, the country resort to different trade free zones commonly known as Special Economic Zones (SEZs). These zones are established by host countries to foster business entities and to free trade in their national borders. In these zones, business and trade laws are implemented differently from the rest of the country. They are located within the countries'national border $^{46}$. The purposes of establishing SEZs are to increase trade, investment, job creation and effective administration. In these areas, special policies regarding investing, taxation, trading, quotas, customs and labor regulations are enforced ${ }^{47}$. The creation of SEZs are meant to attract $\mathrm{FDI}^{48}$ in host countries, trade goods at more globally competitive prices ${ }^{49}$.The SEZs historically were known as Free Zones and Enterpots for centuries for free storage and exchanges. Modern SEZs appeared from late 1950 in the industrial countries. First SEZ was in Shannon Airport in Clare, Ireland. Recent trends in SEZs were witnessed by African Countries with China. There are multiples types of SEZs as practiced and established by host countries around the world., these are i) Free Trade Zones (FTZ), ii) Export Processing Zones (EPZ), iii)Free Zone/Free Economic Zones (FZ/FEZ), iv) Industrial Parks/Industrial Estate (IE), v) Free Ports, vi) Bonded Logistics Parks (BLP), and vii) Urban Enterprise Zones ${ }^{50}$.

Special Zones Framework in Pakistan is regulated by Special Zones Act, $2012^{51}$ and Special Zones Rules, $2013^{52}$ notified in terms of section 40 of SEZ Act, 2012.These legislation are incentive oriented legislation enacted in Pakistan to provide more confidence to foreign investorsto make investment into its economy. China is helping Pakistan to develop RUBA SEZ. At present, there are following Special Economic Zones, planned in Pakistan in collaboration with different countries including China. These are i)RUBA SEZ, ii)China Pakistan Economic Zone, iii)Japanese SEZ, iv) SEZ at

${ }^{45}$ Travel Automation (Pvt.) Ltd v Abacus International (Pvt.) Ltd reported as 2006 CLD 497

${ }^{46}$ Ibid.

47"Special Economic Zones Progress, Emerging Challenges, and Future Directions" (PDF). Washington DC: The International Bank for Reconstruction and Development/The World Bank. 2011. Can be viewed online at https://openknowledge.worldbank.org/bitstream/handle/10986/2341/638440PUB0Exto00Box0361527B0PUB LIC0.pdf(accessedMay 20, 2015)

48"Special economic zones and regional integration in Africa" (PDF). tralac. 2013. Can be viewed online at http://www.tralac.org/files/2013/07/S13WP102013-Woolfrey-Special-economic-zones-regional-integrationin-Africa-20130710-fin.pdf (accessedMay 20, 2015)

${ }^{49}$ "Goldman Sachs says reforms to create $110 \mathrm{mn}$ jobs for economy in 10 yrs". Business Today. March 29, 2014 can be viewed online at http://businesstoday.intoday.in/story/goldman-sachs-says-reforms-to-create-110mn-jobs-for-economy-in-10-yrs/1/204721.html

(accessed May 25, 2015)

${ }^{50}$ Ibid.

${ }^{51}$ Online version of Special Economic Zone Act, 2012 can be viewed at

http://www.na.gov.pk/uploads/documents/1351075194_836.pdf, (accessed June 25, 2015)

${ }^{52}$ Online version of Rules is available at http://boi.gov.pk/UploadedDocs/Downloads/SEZ_RULES.pdf, (accessed June 30, 2015) 
Sialkot Lahore Motorway, v) Industrial Estate in Faisalabad, vi)Karachi Export Processing Zone, Karachi, Sindh, vii)Risalpur Export Processing Zone, viii)Sialkot Port Export Processing Zone, ix) Gujuranwala Export Processing Zone and x) Khairpur Export Processing Zone ${ }^{53}$.

The important features of the SEZ Act are that the approval of Zones are granted on the land over and above fifty acres ${ }^{54}$.The $30 \%$ of the Zone could be allocated for social infrastructure and its utilization. The government is made responsible to make sure of public utilities and transportation links to the Zone and its zero point. Furthermore, the government would devise simple administrative procedures for SEZs in liaison with relevant Federal and Provincial authorities and agencies viz., grant of licenses, sanctions of permits and approvals, following satisfactory customs and other codal requirements. The easy fulfillment of tax or duties/obligations, and support of government in authorization of modern means of communication and e-governance were also provided in the enactment ${ }^{55}$.

The legislation also emphasizes that the labor laws of Pakistan would be applicable to the Zone Enterprises. Moreover, the Board of Investment has been conferred the power to issue special rules for employment of non-Pakistanis in key managerial and technical positions subject of course to necessary approval after adopting consultations process with concerned Ministries and governmental agencies ${ }^{56}$. These rules cater for grant of visas and temporary residence permits, as well as temporary work permits. The dependents of these persons would be treated by these special rules ${ }^{57}$. All these measures show that Government of Pakistan is keen to facilitate foreign investment in Pakistan.

The Act further defines categories of zones. The following categories are given in the Act; i)Free Trade Zone, ii) Export Processing Zone, iii) Multilateral Economic Zone, iv) Regional Development Zone, v) Reconstruction Opportunity Zone, vi) Hybrid Export Processing Zone, vii) Sector Development Zone, or viii) Extra-Territorial Zone ${ }^{58}$. The Extra Territorial Zone would not come under the ambit of the customs territory of Pakistan. By saving this type of zone from custom territory, goods and services from these areas are not treated as export and import ${ }^{59}$. The principles of rebates and other advantages are made applicable on the zones ${ }^{60}$. All incentives under this Act are in furtherance to any other incentives, benefits and protections that are available to Developers or to Zone Enterprises under any other law enforced in Pakistan and in international settlement or treaties of Pakistan ${ }^{61}$. These benefits are legislatively

\footnotetext{
${ }^{53}$ http://boi.gov.pk/InvestmentGuide/SEZ.aspx (accessed June 30, 2015)

${ }^{54}$ See Section 16 of the Act

${ }^{55}$ See section 28 of the Act

${ }^{56}$ See Section 31 of the Act

${ }^{57}$ See Section 31 of the Act, in this section terms and conditions, visa requirement, temporary residence permit and temporary work permits are included. This section is comprehensive provisions, whereby discretion is given to BoI to frame rules in regard to expertise of non-Pakistani and their employment in these SEZs.

${ }^{58}$ See section 2(i)- This Act is equally applicable to all zones prior to coming into force of this Act.

${ }^{59}$ See section $2(\mathrm{n})$ of the Act

${ }^{60}$ See section 33 of the Act

${ }^{61}$ See section 35 of the Act
} 
protected so that the same shall not be withdrawn by successor of any government in Pakistan or due to policy shift and if the changes are necessarily meant to be made, then these changes shall be to the advantage of the Developer or the Zone Enterprise and not otherwise $^{62}$.

One important feature of the SEZ Act, is that certain benefits are given to the Developers of Zones, in case they intend to invest in these SEZ, these benefits are as follows ${ }^{63}$ :

(a) One exemption is given on importation of Capital goods from all customs duties and taxes provided the same are imported for the development, operation and maintenance of any entity working in Economic Zone. BoI has been conferred powers of verification and approval in this regard.

(b) Exemption is also granted for a period of ten years from all taxes on income generated in relation to the development and operation of the Economic Zone.

Whereas on the other hand, all Zone Enterprises are conferred with following benefits ${ }^{64}$ :

(a) Exemption from custom duties and taxes on imported capital goods for the purposes of installation in Economic Zone.

(b) Exemption from all taxes on income for a period of ten year starting from date of confirmation of commencement of commercial operations by the Developer in SEZ.

One important feature in the legislation is the alternative dispute resolution clause. This clause has been inserted to utilize the expertise available at local Center for Mediation so that the investors and developers can more focus towards the success of their undertakings.

The BoI also felt that some existing custom duty related provisions and lack of monitoring thereof may lead to abuse of those incentives by unscrupulous elements. Therefore, appropriate monitoring of the implementation by specialist agency i.e. Federal Board of Revenue (FBR) would be required. Another proposal to limit any possible distortions is to just give zone enterprises and developers only one time exemption for the import of machinery and not to allow this exemption to continue indefinitely as previously envisaged in the Act ${ }^{65}$. In pursuance to section 10 of the SEZ Act, 2012, the Government of Sindh has institutionalized a Special Economic Zone Authority to carry out the purposes of the act within province of Sindh and to safeguard the interest of investors. This Authority being focal person would regulate and supervise the functions and provisions of infrastructures to theses SEZs within the geographically boundaries of Province of $\operatorname{Sindh}^{66}$.

\footnotetext{
${ }^{62}$ See section $35(2)$ of the Act

${ }^{63}$ See section 36 of the Act

${ }^{64}$ See section 37 of the Act

${ }^{65}$ Ibid.

${ }^{66} \mathrm{http}: / /$ www.sbi.gos.pk/seza.php
} 
BoI has proposed certain amendments in the provisions of SEZ Act, 2012. These are deletion of wording of acres as appearing in section 16(2)(a). The section 36(a) will be replaced as "exemption from all customs duties and taxes for all capital equipment imported into Pakistan for the development, operation and maintenance of a SEZ subject to verification by the FBR under the rules made by the Bol". The section 37(a) will be replaced with the wording "one time exemption from customs duties and taxes on import of capital equipment into the SEZ for installation in that zone enterprise subject to verification and approval of the FBR under the rules made by the Bol". A new article will also be inserted as per sources of BoI in the Act which is as follows "if any difficulty arises in giving effect to any provision of this Act, the BoI may, by notification in the official gazette, make such provisions as may appear to be necessary for the purpose of removing such difficulty" ${ }^{\prime 67}$. By making these new amendments, the BoI is empowered to simplify the procedural difficulties of SEZ Act, 2012 in order to achieve its purpose, rather to wait for another amendment or resolution through legislature. These amendments, in fact, are beneficial amendments and such kinds of legislation have never been introduced in Pakistan previously, therefore, the same runs the risk of difficulties in carrying out its object and purposes. In order to remove the same, the legislature has delegated its powers to BoI to make necessary amendments through rules in the original SEZ Act. The one-time exemption on custom duties and taxes for capital equipment meant for development, operation and maintenance of a SEZ is allowable provided that the same fulfills the criteria of verification and approval at the hands of FBR. This is very important in context of development of SEZ on one hand and non-exploitation of import scheme on the other hand by unscrupulous elements in the name of SEZ imports.

Investment Policy, 1997 revolutionized a new dawn in Pakistan in respect of international investments. This policy opened up services, social infrastructure and agriculture sectors for foreign and local investors. The policy is believed to be major causes for integration of modern FDI into Pakistan. It exposed the Pakistan's economy into international market. Prior to this policy, Pakistani foreign investment environment was restricted to manufacturing sector only. Investment Policy of 1997 is one of the fundamental foundations for the gains in FDI inflows over the subsequent decade ${ }^{68}$. The experts believed that it was incentive oriented policy ${ }^{69}$. Following are some of the highlights ${ }^{70}$ of this policy:-

i) Foreign investment on repatriable basis was allowed in Agriculture, Service/Infrastructure and Social sector.

ii) The import tariff on plant, machinery and Equipment was at the standard rate of $10 \%$ and no levy of Sales Tax.

\footnotetext{
${ }^{67} \mathrm{http}: / /$ www.brecorder.com/top-stories/0:/1214382:special-economic-zones-act-amendments-likely-to-attractinvestors/ (accessed June 30, 2015).

${ }^{68}$ Ibid., note 15 ,

${ }^{69}$ AshfaqueH.Khan, Foreign Direct Investment in Pakistan, Policies and Trends. "The Pakistan Development

Review 36:4, Part II (Winter 1997) pp. 959-985.

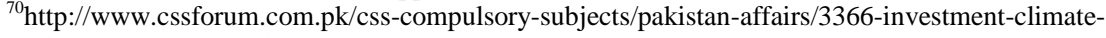

pakistan.html (accessed July 4, 2015)
} 
iii) Foreign investment was allowed in Education, technical/Vocational Training and health and other areas.

iv) $\quad 40 \%$ equity to be held by Pakistan in company/project.

v) Foreign investment equity in the company or project allowed at the level of US\$ 1 million.

vi) Sources of investment would not be probed by any agency ${ }^{71}$.

vii) National Industrial Zones (NIZs) would be launched to promote export oriented units ${ }^{72}$.

viii) Tariff rationalization of both provincial and Federal Level ${ }^{73}$.

ix) At the time of policy, there were 24 different taxes, which were reduced to 5 in the policy.

x) Manufacturing sector has been prioritized into four categories.

a) Value added or export industries

b) High tech

c) Priority industries

d) Agro based industries

xi) Labor laws would be applicable as were applicable in Export Processing Zone

xii) Visa Policy was relaxed

xiii) To improve working relations, labor laws have been revised.

xiv) 100 billion was earmarked to upgrade existing roads and construction $^{74}$.

Successive governments in Pakistan have maintained these policies except a temporary restriction imposed on foreign exchange accounts during 1998, when sanctions were imposed on Pakistan after it exploded nuclear devices. These policies achieved the desired result and FDI increased many fold in the coming years ${ }^{75}$.

\footnotetext{
${ }^{71} \mathrm{http}: / /$ www.pakistaneconomist.com/issue1999/issue49/cover.htm(accessed July 30, 2015)

${ }_{73}^{72}$ Ibid.

${ }^{73}$ Ibid.

${ }^{74} \mathrm{Ibid}$, note 76

${ }^{75}$ S. GhiasulHaque,Impact of Foreign Direct Investment on Exports: A Case Study of Pakistan, http://www.iises.net/download/Soubory/soubory-puvodni/Haq.pdf(accessed August 14, 2015)
} 
After the Investment Policy, 1997, the Investment Policy, 2013 was enforced in the year 2013 by the present Government of Pakistan with the purposes of taking advantage from investment liberalization in the economic world for growth and prosperity ${ }^{76}$. The investment Policy, 2013 is enhancement of Investment Policy, 1997. It reinforced the components of old policy and is consolidation form of existing policies of related line ministries. The thorough revision of existing policy 1997 has made through this policy because of global investment trends, regional trends and experiences ${ }^{77}$. First time, FDI strategy for Pakistan for 2013-17 has been set by the Government ${ }^{78}$. Furthermore, the guiding principles have been inserted as benchmark of attracting investment. These included i) slashing the cost of the business in Pakistan, ii) slashing the processes of business, iii) Simplicity of doing business with industrial clusters and SEZs and iv) linkage of trade, industries and monetary policies for greater conveyance ${ }^{79}$. In nutshell, to sum up, following features are offered to investors for investment in Pakistan in Investment Policy, 2013:-

a) Equity caps by SBP and SECP have been removed.

b) One-window operation by BoI.

c) SEZs Act, 2012 has been promulgated for industry clusterialization.

d) Planning Commission launched the Growth Framework.

e) Four areas productivity, better governance, competitive markets, innovation and entrepreneurship have been identified to closely intersect with Investment Policy, 2013.

The Chapter II of the Investment Policy, $2013^{80}$ emphasizes a liberal investment regime. The salient features of liberal investment regime on the best practices are adopted in the Policy which has been taken from the investment practices around the world.Some of few salient features of liberal investment regime has been given in clause 2.1: -

1) "Free entry for Foreign Investors (all sectors are included for investmentunless specifically prohibited like national security, public safety such as arms and ammunitions, high explosives, radioactive substance, security, currency and consumable oil".

2) "No minimum requirement of foreign equity. Foreign investors shall be at liberty to repatriate profits in the currency of origin of investment, subject always to Act, 1976 and Foreign Exchange Manual".

\footnotetext{
${ }^{76}$ Investment Policy, 2013 retrieved on 16-05-2015 from online http://www.sbi.gos.pk/pdf/SEZA/INVESTMENT\%20POLICY-2013.pdf (accessed August 14, 2015)

${ }^{77}$ See Clause 1.2 of the Policy: Evolutionary Enhancement of 1997 investment Policy

${ }^{78}$ See clause 1.3 of the Policy: Goals of the Policy

${ }^{79}$ See clause 1.4 of the policy: Guiding Principles

${ }^{80}$ See Chapter II of the policy: Liberal Investment Regime
} 
3) "Ease of registration and entry permit has been given in clause 2.2. All corporate registration would be under Companies Ordinance, 1984. Foreign investors and foreign investment companies are required to comply with the compliance of two enactments i.e. Companies Ordinance, 1984 and Competition Act, 2010".

4) "Online registration of foreign investor by BoI entering or operating in Pakistan, which serves as a notification to Government of Pakistan of presence of foreign investor. Initial period of approvals are for the period of five years".

5) "SBP and SECP have relaxed equity caps in this policy".

6) "Foreign investors are entitled to lease the land without limitation".

7) "Restriction on foreign real estate delivers have been removed".

8) "Foreign investors are allowed to hold $60 \%$ stake in agriculture project".

9) “In corporate farming, 100\% equity are allowed".

10) "The pioneer industry has extra advantages".

11) "SMEs are given preferences".

12) "Alternative and Renewable Energy is earmarked as one of the prime sector for foreigner investors. Alternative and Renewable Energy Board has been established for facilitation of foreign investors".

In Chapter III ${ }^{81}$, the investment protection is emphasized to be prime object of import Policy, like in the volatile law and order situation, investors' rights are best protected. The rights of investors as given in the policy are fair and equitable treatment without discrimination and right to due process of law as per Foreign Private Investment Promotion and Protection Act, 1976 and Protection of Reforms Act, 1992.The BoI is also planning to develop a model text of BIT with assistance of relevant law division, which will be helpful for protection to investment on reciprocity basis. The insurance cover has also been secured from Multilateral Investment Guarantee Agency (MIGA) of World Bank for providing insurance to investors' projects in Pakistan. The Arbitration (International Investment Disputes) Act, 2011 enables the investors to go to higher courts. Recognition and Enforcement of Arbitral Awards Act, 2011 has been also promulgated to safeguard the rights of investors. The security of foreign investors from airport to airport in order to make them feel secured has been substantially included in the Policy, 2013. The Intellectual Property Rights Protection would be ensured by Government at any cost, for which separate window has been established by BoI.

${ }^{81}$ See chapter III of the Policy, 2013. They are investment protection provisions providing for any eventualities causing affects on the investment and as to how the rights of investors would be protected given law and order situation. 
The Chapter $\mathrm{IV}^{82}$ provides for establishment of Special Economic Zones with the aim of reducing the cost of doing business in Pakistan. In this regard, Special Economic Zones Act, 2012 has been promulgated by the Government of Pakistan. The Chapter $\mathrm{V}^{83}$ of the policy talks about facilitation to foreign investors such as comprehensive and investors' friendly visa policy. For Pakistan Diaspora a dedicated cell has been established in BoI. Women entrepreneurs are also encouraged in the policy. The Chapter $\mathrm{VI}^{84}$ gives the details of strategizing the policy for implementation and development. Five years investment strategy has been set to achieve investment targets. For implementation and development, seven points including private and public sector dialogue has been provided in the policy.

The most of Foreign Investment Laws of Pakistan are based upon the Bilateral Investment Treaties as these contain provisions affecting rights and liabilities of investors-state relationship. Bilateral Investment Treaties are an international agreement governing terms and conditions of private investment by nationals and corporations of one state with another. The investment of this kind is called FDI. In nineteenth century, prior to BITs, there existed Friendship, Commerce and Navigator Treaty $(\mathrm{FCN})^{85}$. Most of the BITs of the world provides for fair and equitable treatment, protection from expropriation, free transfer of means, full protection and security. Important feature of BIT is that they allow for a mechanism of alternative disputes resolution, whereby investors in case of dispute with state, can invoke the jurisdiction of ICSID for resolution of their investment dispute ${ }^{86}$.The First BIT of the world was signed between Pakistan and Germany in $1949^{87}$ and at present, there are 2500 BITs in force around the world i.e. between countries to countries and between the investors and state ${ }^{88}$.

So far Pakistan has 48 Bilateral Investment Treaties with different countries around the world ${ }^{89}$.Out of these, 26 are in force ${ }^{90}$. But despite these long list of BITs, Pakistan has failed to attract valuable FDI from the investors ${ }^{91}$. In wake of these situations the Government official has suggested model template of BIT, which is considered to serve as basis for evolving the future investment negotiations ${ }^{92}$. The important aspect of model template is that they contain arbitration clauses which provide for settling

${ }^{82}$ See chapter IV of the Policy, 2013. This chapter talks about creation of Special Economic Zones with the purpose of reducing the cost of doing business. It furthers says that for this purpose, Special Economic Zones Act, 2012 has been promulgated.

${ }^{83}$ See chapter V of the Policy, 2013. This chapter emphasizes hassle free visa policy for foreign investors.

${ }^{84}$ See chapter VI of the Policy, 2013. This chapter highlights strategization of import policy for its implementation and development.

${ }^{85}$ W. Michael Reisman et al.,"International Law in Comparative Perspective" (2004), p. 460

${ }^{86}$ "Umbrella Clauses In Bilateral Investment Treaties: Of Breaches of Contract, Treaty Violations, and the Divide Between Developing and Developed Countries in Foreign Investment Disputes", George Mason Law Review (14 Geo. Mason L. Rev. 135) (2007)

${ }^{87}$ AmericoBevigliaZampetti and Pierre Sauve,International Investment, Research Handbook in International Economic Law (E. Elgar, 2007), p215; http://www.bilaterals.org/article-print.php3?id_article=717(accessed December 15, 2015)

${ }^{88}$ Principles of International Investment Law, Oxford, 2008, by Rudolf Dolzer and ChristophSchreuer, at page

2; UNCTAD, World Investment Report (2006) XVII, 26

${ }^{89} \mathrm{http} / / /$ boi.gov.pk/InvestmentGuide/BITs.aspx(accessed January 30, 2016)

${ }^{90} \mathrm{http} / / /$ boi.gov.pk/UploadedDocs/Downloads/InvestmentGuide.pdf(accessed February 15, 2016)

${ }^{91} \mathrm{http}: / /$ www.dawn.com/news/1038303(accessed March 20, 2016)

${ }^{92}$ Ibid. 
disputes in local courts than going into international arbitration. This model was created by Pakistan in or around $2006^{93}$. Recently, the US-Pak BIT is under negotiation, but Pakistan is moving very cautiously on this BIT after US has introduced a new draft that carries stringent clauses with far reaching implication ${ }^{94}$.

The existing International Investment Treaty Model usually contains blanket provisions to cater to diverse relationship of state with other potential capital exporting countries ${ }^{95}$. The most of BITs Pakistan has signed previously do not reflect mutually negotiated picture. They contain provisions more suitable for investors and none for people of Pakistan $^{96}$. Due to deficiency, Pakistan has now intends to change its BITs regime to streamline it in line with modern investment laws and best practices ${ }^{97}$. In this regard, BOI has been conferred statutory powers under clause $9(\mathrm{~m})$ (Functions of BOI) of BoI Ordinance, 2001 to negotiate and finalize agreements for protection and promotion of investment with other countries ${ }^{98}$.

\section{Conclusion}

Pakistan after independence has long way travelled in attracting foreign direct investments into its territory. The investor friendly laws, rules and regulations and financial incentives not only are encouraging investment at vast scale, but the same is also creating more jobs and employment opportunity to people of Pakistan. The per capita of every individual is likely to be increased by passage of time. Need of hour is that the Government of Pakistan should win the foreign investment by giving priority and removing major hurdles, like energy, law and order crises, so that much needed and valuable foreign exchange and foreign investment may start flowing in its economy. The existing laws on the subject are obsolete, which need updation and reexamination especially Bilateral Investment Treaties in the light of modern international investment law and its best practices. China and India are one of few examples that have seen some of largest FDI inflows despite having stringent restrictions on capital flows. So, let signing of BITs would not solve the problems, but more pragmatic approach should be adopted like developing educated work force and technology-oriented advancement towards wooing the foreign investment.

The laws related to arbitration and arbitral awards are still facing problems in Pakistan due to its non-practicality. It is also argued that the Recognition and Enforcement (Arbitration Agreements and Foreign Arbitral Awards) Act, 2011contains error that could seriously stop parties hoping to rely on international arbitration agreements in Pakistan. In this enactment, only High Courts of Pakistan are made the ultimate courts

\footnotetext{
${ }^{93}$ MahnazMalik, International Law Protections for Foreign Investment in Pakistan, (Karachi: Overseas Investors Chamber of Commerce and Industry, 2010) 25

${ }^{94} \mathrm{http} / / /$ tribune.com.pk/story/683275/us-investment-government-to-tread-carefully-on-bilateraltreaty/(accessed April 15, 2016)

${ }^{95}$ NidaMehmood,Pakistan's BIT dilemma, http://nation.com.pk/columns/15-Jul-2013/pakistan-s-bitdilemma(accessed May 12, 2016)

${ }^{96}$ Ibid.

${ }^{97}$ https://weeklycorporateambassador.wordpress.com/2015/02/14/pakistan-to-revise-bilateral-investmenttreaty-regime/(accessed May 12, 2016)

${ }^{98}$ Ibid.
} 
of law for enforcement of awards, whereas under Civil Procedural Code, commercial disputes are referable to the local courts for trial. These lower courts have no jurisdiction to recognize arbitration agreements in accordance with the New York Convention in respect to their jurisdiction.

\section{Bibliography}

\section{Books}

Americo Beviglia Zampetti and Pierre Sauve, ed. 2007, International Investment.Research Handbook in International Economic Law.Cheltenham [etc.]: Edward Elgar

ImadA.Moosa.,ed. 2002, Foreign Direct Investment: Theory, Evidence and Practice. New York: PALGRAVE.

Mahnaz Malik.,ed. 2010. International Law Protections for Foreign Investment in Pakistan.Karachi: Overseas Investors Chamber of Commerce and Industry.

Rudolf Dolzer and ChristophSchreuer. 2008., Principles of International Investment Law. Oxford,Oxford University Press.

Reisman, Arsanjani, Westerman,Siegfried Wiessner., ed. 2004.International Law inContemporary Perspective (University Casebook Series). New York: Foundation Press.

\section{Online}

Calvin S.GoldmanQC., ed. 2013.The Foreign Investment Regulation Review. London: LawBusiness Research Ltd,http://www.mjlalegal.com/uploads/1/7/8/7/17874169/foreign_investment_regulation s_-pakistan.pdf(accessed May 09, 2015)

\section{Articles}

Alishba Tahir, 2014, Developing Countries International Investment Policies, Unveiling Pakistan Paradoxies, 2014, WORKING

PAPER,http://www.cuhk.edu.hk/law/proj/BITSel/download/Alishba_Tahir(2014).pdf(a ccessed May 09, 2015)

Ashfaque H.Khan, 1997, Foreign Direct Investment in Pakistan, Policies and Trends, Winter 1997, The Pakistan Development Review 36:4, Part II

Jarrod Wong., 2008, Umbrella Clauses In Bilateral Investment Treaties: Of Breaches of Contract, Treaty Violations, and the Divide Between Developing and Developed Countries In Foreign Investment Disputes, George Mason Law Review (14 Geo. Mason L. Rev. 135). http://papers.ssrn.com/sol3/papers.cfm?abstract_id=1260897(accessed January, 2016) 
Sean Woolfrey, 2013,Special economic zones and regional integration in Africa. tralac. http://www.tralac.org/files/2013/07/S13WP102013-Woolfrey-Special-economic-zonesregional-integration-in-Africa-20130710-fin.pdf(accessed May 20, 2015)

S.GhiasulHaque, Impact of Foreign Direct Investment on Exports: A Case Study of Pakistan, http://www.iises.net/download/Soubory/soubory-puvodni/Haq.pdf(accessed August 14, 2015)

Syed Bulent Sohail \& Shahid Jamil, Legislative Updates, http://www.counselpakistan.com/vol-3/from_the_editors/by_shaharyar_nashat.php (accessed May 20, 2015)

Thomas Farole., Gokhan Akinci., 2011, Special Economic Zones, Progress, Emerging Challenges, and Future Directions. Washington DC: The International Bank for Reconstruction and Development/The World Bank.

https://openknowledge.worldbank.org/bitstream/handle/10986/2341/638440PUB0Exto0 0Box0361527B0PUBLIC0.pdf(accessed May 20, 2015)

\section{Magazine Articles}

Prof. Dr. Khawaja Amjad Saeed, 1999, Foreign direct investment: A review, Dec 0612,http://www.pakistaneconomist.com/issue1999/issue49/cover.htm, (accessed July 30, 2015)

Mubarak Zeb Khan, 2013, Bilateral Treaty Investment Model, The Daily Dawn, August 26.http://www.dawn.com/news/1038303(accessed March 20, 2016)

NidaMehmood, 2013, Pakistan's BIT dilemma, The Daily Nation, July 15.http://nation.com.pk/columns/15-Jul-2013/pakistan-s-bit-dilemma(accessed May 12, 2016)

PTI, 2014, Goldman Sachs says reforms to create $110 \mathrm{mn}$ jobs for economy in $10 \mathrm{yrs}$. Business Today. March29.http://businesstoday.intoday.in/story/goldman-sachs-saysreforms-to-create-110-mn-jobs-for-economy-in-10-yrs/1/204721.html(accessed May 25, 2015).

ShahbazRana, 2014, US investment: Government to treat carefully on bilateral treaty, The Daily Express Tribune, March 16.http://tribune.com.pk/story/683275/usinvestment-government-to-tread-carefully-on-bilateral-treaty/(accessed April 15, 2016)

Weekly Corporate Ambassador, 2015, Pakistan to revise Bilateral Investment Treaty regime, February, 02.https://weeklycorporateambassador.wordpress.com/2015/02/14/pakistan-to-revisebilateral-investment-treaty-regime/(accessed May 12, 2016) 


\section{Laws/Legislation}

Arbitration (international Investment Dispute) Act, 2011.http://www.na.gov.pk/uploads/documents/1304997073_250.pdf, (accessed May $12,2015)$

Board of Investment Ordinance, 2001.http://boi.gov.pk/AboutUs/BOIOrdinance.aspx(accessed May 11, 2015)

Foreign Private Investment (Promotion \& Protection) Act 1976,http://boi.gov.pk/UploadedDocs/Downloads/InvestementActs.pdf, (accessed May $11,2015)$

Recognition and Enforcement (International Arbitration Agreements and Foreign Arbitral Awards) Act, 2011. http://www.na.gov.pk/uploads/documents/1311664767_452.pdf, (accessed May 20, 2015)

Special Economic Zones Act, 2012, http://www.na.gov.pk/uploads/documents/1351075194_836.pdf, (accessed June 25, 2015)

Special Economic Rules, 2013,http://boi.gov.pk/UploadedDocs/Downloads/SEZ_RULES.pdf, (accessed June 30, 2015)

\section{Webliography}

Investment in Pakistan, KPMG TaseerHadi\&

Company.http://www.kpmg.com/PK/en/IssuesAndInsights/ArticlesPublications/Docum ents/Investment-in-Pakistan2013.pdf(accessed January 1, 2015)

Investment Policy, 2013, Board of Investment of Pakistan, http://www.boi.gov.pk/UploadedDocs/Downloads/InvestmentGuide.pdf, (accessed May 09, 2015)

List of cases concluded by ICSID over Pakistan under different BITs.https://icsid.worldbank.org/apps/ICSIDWEB/cases/Pages/AdvancedSearch.aspx?r ntly=ST105 (accessed May 10, 2015)

The official website of World Association of Investment Promotion Agencies (WAIPA),http://waipa.org/ (accessed May 15, 2015)

Board of Investment Pakistan, Special Economic Zones Framework in Pakistan,http://boi.gov.pk/InvestmentGuide/SEZ.aspx, (accessed June 30, 2015)

Sindh Board of Investment, Special Economic Zones Authority, http://www.sbi.gos.pk/seza.php, (accessed June 30, 2015) 
AMANULLAH BASHAR, Investment Climate in Pakistan, CSS forum, Civil Service of Pakistan,http://www.cssforum.com.pk/css-compulsory-subjects/pakistanaffairs/3366-investment-climate-pakistan.html, (accessed July 4, 2015)

Board of Investment of Pakistan, Bilateral investment Treaty (BITs)http://boi.gov.pk/InvestmentGuide/BITs.aspx, (accessed January 30, 2016)

\section{Case Laws/Precedents}

(Tikka Iqbal Muhammad Khan versus General Pervez Musharraf and others),

PLD 2008 Supreme Court, page 25 and 178

(Travel Automation (Pvt.) Ltd v Abacus International (Pvt.) Ltd) 2006 CLD 497

(Societe General Surveillance versus Pakistan), 2002 SCMR 1694 